IBAD Sosyal Bilimler Dergisi

IBAD Journal of Social Sciences

dergipark.org.tr/ibad

IBAD, 2021; (10): 202-219

DOI: $10.21733 /$ ibad. 879341

Özgün Araştırma / Original Article

\title{
Ortaokul Öğrencilerinin Evrensel Fen Okuryazarlık Düzeyleri
}

Secondary School Students' Universal Science Literacy Levels

\section{Emel Salc1 ${ }^{1}$}

Abdullah Aydın ${ }^{2 *}$

* Sorumlu yazar

Corresponding author

${ }^{1}$ Öğretmen, Kastamonu Özel Bahçeşehir Koleji, Türkiye Teacher, Kastamonu Private Bahcesehir College, Turkey emel.kiray@bahcesehir.k12.tr

ORCID ID 0000-0001-9184-6412

${ }^{2}$ Prof. Dr., Kastamonu Üniversitesi, Türkiye

Prof. Dr., Kastamonu University, Turkey

aaydin@kastamonu.edu.tr

ORCID ID 0000-0003-2805-9314

Makale geliş tarihi / First received : 12.02.2021

Makale kabul tarihi / Accepted : :09.03.2021

\section{Bilgilendirme / Acknowledgement:}

Yazarlar aşağıdaki billgillendirmeleri yapmaktadırlar:

1- Araştırmacıların katkı oranları eşittir.

2- Makale, birinci yazarın yüksek lisans tezinden üretilmiştir.

3- Makalenin yazarları arasında çıkar çatışması bulunmamaktadır.

4- Araştırmada kullanılan ölçek için e-posta yoluyla gerekli izin alınmıştır.

5- Araştırma için, Kastamonu Üniversitesi Sosyal ve Beşeri Bilimler Araştırma ve Yayın Etik Kurul Başkanlığı'ndan (Tarih: 25.12.2020; Sayı: 4/22) gerekli izinler alınmıştır.

6- Bu makalede araştırma ve yayın etiğine uyulmuştur.

This article was checked by iThenticate. Similarity Index $17 \%$

\section{Atıf bilgisi / Citation:}

Salcı, E., Aydın, A. (2021). Ortaokul öğrencilerinin evrensel fen okuryazarlık düzeyleri. IBAD Sosyal Bilimler Dergisi, (10), 202-219. 
Öz

$\mathrm{Bu}$ araştırmanın amacı, Kastamonu İl Merkezindeki devlet ortaokullarında öğrenim gören altıncı, yedinci ve sekizinci sınıf öğrencilerinin evrensel fen okuryazarlık düzeylerini belirlemek ve bu düzeyin anne eğitim seviyesine, baba eğitim seviyesine, sınıf seviyesine ve cinsiyete göre değişip değişmediğini tespit etmektir. Bu amaç doğrultusunda, 1674 öğrenciye Evrensel Fen Okuryazarlık Ölçeği (EFOYÖ) uygulanmıştır. Nicel araştırma deseninin kullanıldığı bu araştırma, tarama modelindedir. Araştırmadan elde edilen verilerin analizinde SPSS paket programından yararlanılmıştır. Verilerin analizi sonucunda, öğrencilerin evrensel fen okuryazarlık düzeyinin "yüksek" olduğu belirlenmiştir. Ayrıca evrensel fen okuryazarlık puanlarına, anne ve baba eğitim seviyesinin, sınıf seviyesinin ve cinsiyetin etkisinin olduğu tespit edilmiştir. Öğrencilerin evrensel fen okuryazarlık düzeylerini artırmak için onların teknolojik tasarımları incelemeye, müzeleri ziyaret etmeye, bilim insanlarının buluşlarını hikayeleştirmeye, bilimsel dergi ve belgeselleri takip etmeye ve yaratıcılıklarını kullanarak teknolojik araç ve gereç tasarlamaya teşvik edilmeleri önerilir.

\section{Anahtar kelimeler}

Evrensel fen okuryazarlık, ortaokul öğrencileri, anne ve baba eğitim seviyesi, sınıf seviyesi, cinsiyet

\section{ABSTRACT}

The purpose of this study is to determine the universal science literacy levels of sixth, seventh and eighth grade students in public secondary schools in the Kastamonu Province and to determine whether this level changes according to according to the education level of the mother, the education level of the father, the grade level and gender. For this purpose, Universal Science Literacy Scale (USLS) was applied to 1674 students. This research using quantitative research design is in the survey model. SPSS package program was used to analyze the data obtained from the research. As a result of the analysis of the data, it was determined that the universal science literacy level of the students was "high". In addition, it was determined that universal science literacy level, parents' education level, grade level and gender have an effect. It is recommended that students are encouraged to study technological designs, visit museums, narrate scientists' discoveries, follow scientific journals and documentaries, and design technological tools and equipment using their creativity to increase their universal science literacy level.

\section{Keywords}

Universal science literacy, secondary school students, parents' education level, grade level, gender 


\section{GíRiş}

Küreselleşen toplumda eğitimcilerin ve hazırlanan programların en önemli amacı, öğrencileri küreselleşen bu dünyada yaşamlarını devam ettirebilecek ve gerektiğinde sorumluluk alabilecek bireyler olarak yetiştirmektir (Mun vd., 2015). Bu şekilde yetiştirilen öğrenciler, küresel 1sınma, genetiği değiştirilmiş organizma, kök hücre araştırmaları, nano teknolojiler, petrol sızıntıları vb. sosyo-bilimsel konularda fikrini söyleyebilen, bilimsel bilgilerden yararlanarak karar verebilen ve küreselleşen toplumun yararları için sorunları çözebilen fen okuryazar bireyler olacaklardır (Boyes, Skamp ve Stanistreet, 2009; Mueller ve Zeidler, 2010; Roth ve Lee, 2004; Zeidler, Herman, Ruzek, Linder ve Lin, 2013).

Toplumlar ekonomik ve sosyal gelişimlerini devam ettirebilmeleri için her alanda yeni bilgiye ve teknolojiye ihtiyaç duymaktadırlar. Duyulan bu ihtiyaç ülkelerin diğer ülkelere olan bağımlılı̆̆ını da beraberinde getirmektedir. Bu nedenle ülkeler, bilgi ve teknolojiyi alıcı konumundan çıkıp üretici konumuna geçmeyi hedefleyerek vizyonlarını bu yönde güncellemiş ve buna paralel olarak da eğitime ayrılan bütçeyi ve yapılan yatırımları da arttırmışlardır (Yetişir, Batı, Kahyaoğlu ve Birel, 2018). Geçmişte bu denli ciddi etkiler yaratmasa da, yaşanan hızlı ekonomik, sosyal, bilimsel ve teknolojik gelişmelerin etkisi günümüzde hiç olmadığı kadar açık bir biçimde görülmektedir. Küreselleşme, ekonomik rekabet, teknoloji ve bilişimdeki değişim ile paralel olarak da hayatımızı etkilemeye devam edecektir (MEB, 2006). Tüm bunlar dikkate alındığında ülkelerin güçlü bir geleceklerinin olabilmesi için her vatandaşının iyi bir fen okuryazarı olarak yetiştirilmesi gerekliliği ortaya koyulmuş ve bu noktada da fen bilimleri dersinin anahtar bir rol üstlendiği kaçınılmaz gerçek olmuştur (Kurtuluş ve Çavdar, 2011).

Kültürel kökeni çok eski yıllara kadar giden fen okuryazarlığı kavramı ilk defa Paul DeHart Hurd tarafından 1950'li yılların sonlarına doğru ortaya atılmış (Hurd, 1958) ve bunu takiben bir çok alanda okuryazarlık terimi farklı alanlar için de kullanılmaya başlanmıştır (Cappellaro, 2018). Fen okuryazarlığı kavramı zamanla farklı anlamlar ve boyutlar kazandığı görülmektedir (Bybee, 1997). Fen okuryazarlığı; doğal dünyayı ve onun üzerinde insanlar tarafından meydana getirilen değişiklikleri anlamak, gerektiğinde karar verebilmek için bilimsel bilgiyi kullanmak ve sorunları belirleyerek çözüm yolları bulmak olarak tanımlanabilir. Fen okuryazarlığı sadece fen kavramları hakkında bilgi sahibi olmayı değil aynı zamanda bilimsel sorgulamayı içermektedir (OECD, 2019). Fen okuryazarı bireyler, fen bilimlerine ilişkin temel bilgilere (Biyoloji, Fizik, Kimya, Yer, Gök ve Çevre Bilimleri, Sağlık ve Doğal Afetler) ve doğal çevrenin keşfedilmesine yönelik bilimsel süreç becerilerine sahiptirler. Bu bireyler, kendilerini toplumsal sorunlarla ilgili problemlerin çözümü konusunda sorumlu hisseder, yaratıcı ve analitik düşünme becerileri yardımıyla bireysel veya işbirliğine dayalı alternative çözüm önerileri üretebilirler (MEB, 2013).

American Association for the Advancement of Science (AAAS) (1993) fen eğitiminin önemli amaçlarından birisini, öğrencilerin fen ve teknoloji okuryazarlık seviyesinin artırılması şeklinde belirtmektedir. Fen eğitiminde; fen kavramlarının daha iyi anlaşılması, öğrencilere bilimsel süreç becerilerinin kazandırılması ve bilimin doğasının üzerine temellendirilmesi üzerinde durulmakta ve sedece bu boyutlarla sınırlı kalmayacak şekilde gerçekleştirilmesi gerektiği belirtilmektedir. Fen okuryazarlığı kavramının gelişmiş ülkelerde yerini alması ile birlikte, fen okuryazarı bireylerin yetiştirilmesi öğretim programları içerisine de dahil edilmeye başlanmıştır. Gelişmiş ülkelerin eğitim programlarının incelenmesi ile öğretmenin 
aktif, öğrencilerin pasif olduğu, öğretmenin bilgi aktardığı öğrencinin aktarılan bilgiyi sorgusuz kabul ederek ezberlediği edilgen program anlayışının terk edildiği görülmüştür. $\mathrm{Bu}$ gelişmeler doğrultusunda da eğitim programımız revize edilmiş, öğretmen ve öğrencinin rolü yeniden tanımlanmıştır. Öğretmen bilgiyi aktaran konumundan sıyrılıp, öğrenim sürecini yönlendiren, öğrenme için uygun ortamı ve materyali hazırlayan, öğrenciyle birlikte öğrenen kişi olarak tanımlanmıştır. Öğrenci ise bilgiyi keşfeden kişi olarak tanımlanmıştır. Öğrenci bilgiyi keşfettikçe ilgisi artacak, öğrenmeyi öğrenecek, araştıracak, akıl yürütecek ve sorumluluk alarak süreçte aktif rol oynayacaktır (MEB, 2013).

Çocuk doğuştan gelen bir içgüdü ile çevresindeki her şeye ilgi duyar, onları tekrar tekrar inceler ve öğrenmeye çalışır. Öğrenirken sürekli inceleme ve araştırma yapar. Çocuk çevresindeki olaylarla, sınıfta öğrendikleri arasında iyi bir bağ kurmayı becerebilir. Sınıfta anlatılan fen konuları ile doğada oluşan gerçek fen olayları arasında bağ kurulabildiği zaman çocuğun öğrendiği fen konuları ile çevresinde gördüğ̈̈ gerçek fen olaylarının birbirinin aynı olduğunu anlayabilir (Soylu, 2004). Bu nedenle çocukların yeterli düzeyde eğitim ve öğretim görmelerinin yanında, bir bakıma fen alanında da okuryazar olmaları önemlidir (MEB, 2005; 2013). Çevreleri ve dünya ile aktif bir biçimde ilgilenen, anlamlı sorular sorarak gözlemler yapan, veriler toplayıp bunları analiz edebilen ve analiz sonuçlarını sunabilen, başkalarıyla uygarca iletişim kurabilen, bilgili ve yetenekli fen dalında okuryazar bireyler yetiştirmek yeni fen bilimleri dersi öğretim programının ana hedeflerindendir (Gömleksiz vd., 2006; MEB, 2018).

Fen bilimleri dersinde öğretmenler tarafından, öğrencilerinin fikirlerini rahatça ifade edebilmelerini, düşüncelerini farklı gerekçelerle destekleyebilmelerini ve arkadaşlarının iddialarını çürütmek amacıyla karşıt argümanlar geliştirebilmeleri için bilimsel olgulara yönelik yarar-zarar ilişkisini tartışabilecekleri ortamlar oluşturulmalıdır. Öğretmenler, öğrencilerinin geçerli verilere dayalı oluşturdukları iddiaları haklı gerekçelerle sundukları tartışmalarda yönlendirici ve rehber rolü üstlenmelidir (MEB, 2018). Bahsi geçen tüm kavramlar aslında fen okuryazarlığının temelini oluşturmaktadır. Ülkemizin üreten ülkeler arasında yer alabilmesi için, öğrencilerini araştıran, sorgulayan, keşfeden, oluşturduğu argümanlar sonucunda çalışmalarını ürüne dönüştürebilen bireyler olarak yetiştirmek isteyen eğitim vizyonumuzda sadece fen bilimleri öğretmenlerinin değil, eğitim öğretimin herhangi bir basamağında yer alan tüm öğretmenlerin iyi birer fen okuryazarı olmaları, olayları farklı açılardan değerlendirmeleri, zihinsel yeteneklerini geliştirmeleri, problem çözmede bilimsel süreç becerilerini kullanmaları gerekmektedir. Böyle öğretmenler olduğu sürece sinıf ortamlarında paylaşımın arttı̆̆ı, çözümler üreterek bu çözümleri gündelik yaşantılarına uyarlayabilen aktif bir sınıf ve öğrenciler oluşacaktır. Bu nitelik özelde fen bilimleri dersinde, genelde de tüm derslerde performansı etkileyecek ve eğitim sistemi istenilen yönde gelişecektir (Yetişir ve Kaptan, 2007). Fen okuryazarı bir bireyin özellikleri Şekil 1'de gösterildiği gibi özetlenmiştir. 
Şekil 1. Fen Okuryazar Bireyin Özelliklerine Yönelik Model (Kaya ve Bacanak, 2013)

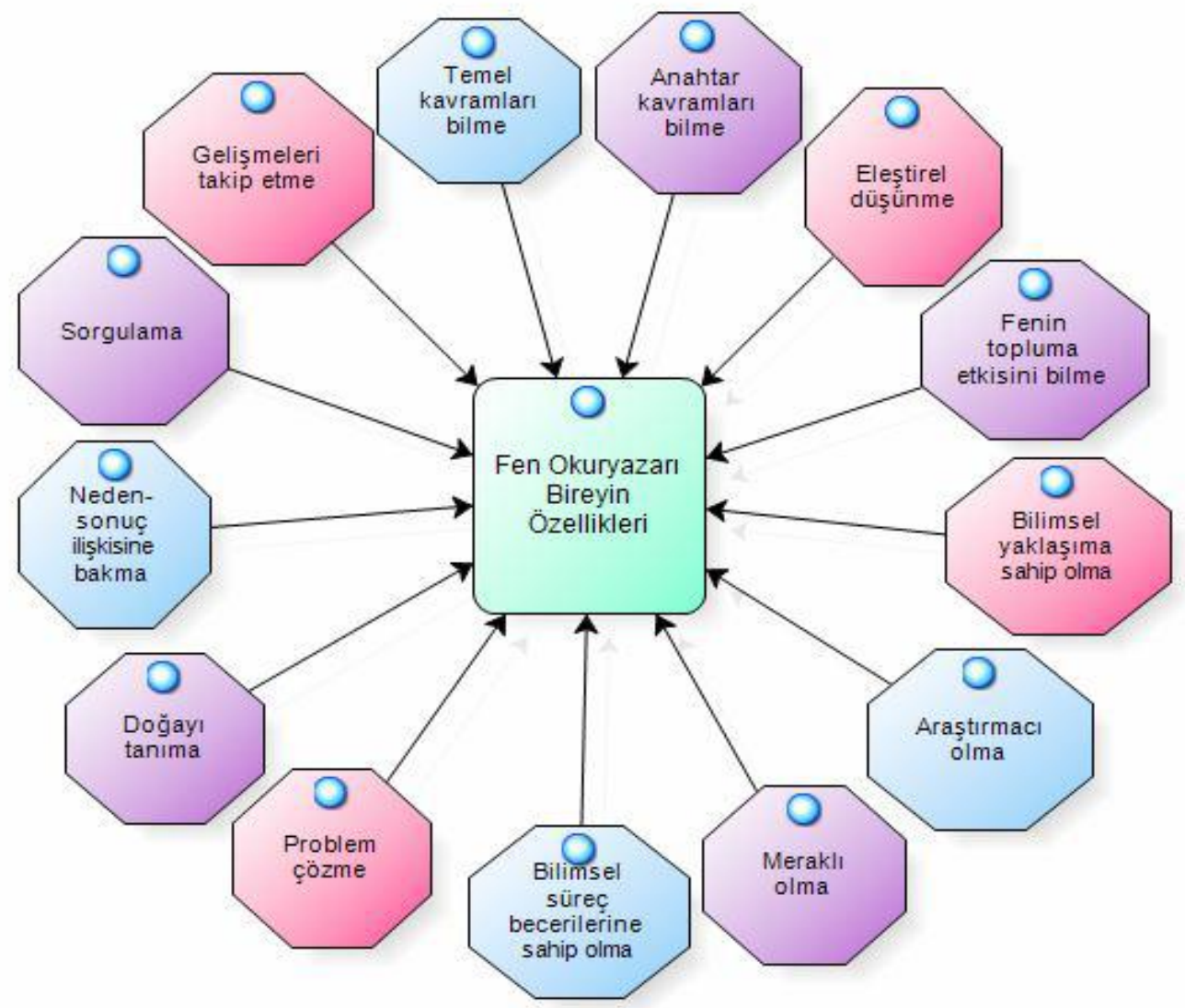

Programme for International Student Assesment (PISA), Uluslararası Öğrenci Değerlendirme Programı uygulamasıyla ve Amerika Birleşik Devletleri'nin öncülük yaptığ 1 Trends in International Mathematics and Science Study (TIMSS), Uluslararası Matematik ve Fen Eğilimleri Araştırması değerlendirme testleriyle fen okuryazarlığı uluslararası bir boyuta ulaşmıştır.

PISA, 15 yaş civarındaki öğrencilerin, aldıkları zorunlu eğitim dönemimin sonunda hayata hazır oluş durumlarını belirlemek ve öğrencilerin fen okuryazarlık düzeylerini ölçmek için yapılan uluslararası bir testtir. 2000 yılından itibaren üç yılda bir yapılan PISA'nın objektif göstergeleri ile ülkeler, katılan diğer ülkeler arasında ne durumda oldukları hakkında bilgi sahibi olurlar. Eğitim durumlarına ve uygulayacakları politikalara yön verirler. Katılımcı ülkeler, bu uygulamanın sonuçlarına göre bir rapor hazırlayarak durum analizi yaparlar (MEB, 2019). PISA sınavlarına katılan Türkiye, OECD ülkeleri ve diğer ülkelerin yıllara göre fen okuryazarlık puan ortalamaları Tablo 1'de verilmiştir.

Tablo 1. Yıllara Göre Ülkelerin Fen Okuryazarlık Puan Ortalamaları (MEB, 2019)

\begin{tabular}{llccccc}
\hline & \multicolumn{6}{c}{ Yillar } \\
\cline { 2 - 7 } & & 2006 & 2009 & 2012 & 2015 & 2018 \\
\cline { 2 - 7 } Ülke & 498 & 495 & 501 & 493 & 489 \\
\cline { 2 - 7 } & Türkiye & 424 & 454 & 463 & 425 & 468 \\
\cline { 2 - 7 } & Diğer Ülkeler & 478 & 471 & 477 & 465 & 458 \\
\hline
\end{tabular}


Dünyanın en kapsamlı eğitim araştırması olan ve 2003 tarihinden itibaren Türkiye'nin de katıldığı PISA sonuçlarına göre, Türkiye fen okuryazarlığında OECD ülkeleri arasında Tablo 1'de gösterildiği gibi ortalamanın altında kalmıştır. Sadece 2018 yılında OECD ülkelerinin altında bir ortalamaya sahip olsa da katılan tüm ülkeler içerisinde ilk defa ortalamanın üstüne çıkmıştır (MEB, 2019; Anıl, Özkan ve Demir, 2015).

Evrensel fen okuryazarlık kavramı tanım olarak fen okuryazarlık kavramına benzese de daha geniş kapsamlıdır. Teknolojinin hızla geliştiği dünyada, toplumdaki her bir bireyin çevresindeki gelişmelerden haberdar olması, onların fen okuryazarlıklarına ve evrensel bir vatandaş olarak görülmelerine bağlıdır. Tal ve Kedmi (2006) araştırmalarının sonucunda, öğrencilerin gerek bireysel gerekse grup olarak fenle ilgili sosyal konular ve toplumdaki yansımaları hakkında bilgi sahibi olduklarında, olayları analiz edebilmeleri, karar verebilmeleri ve konuyla ilgili tutum geliştirip harekete geçebileceklerinden bahsetmişlerdir.

Güncellenen 2013 ve 2018 fen bilimleri dersi öğretim programlarında fen okuryazarlığı, sadece bilişsel bilgi anlayışıyla sınırlı kalmayıp, duyuşsal becerilerinde önemli olduğu bir anlayış haline gelmiştir. Özellikle mevcut program, 21. yüzyıl becerileriyle zenginleştirilip analitik düşünme, iletişim ve takım çalışması, karar verme ve girişimcilik gibi becerileri daha fazla vurgulamaya önem vermiştir (Can ve Çelik, 2020). Buradan hareketle, sosyal ve toplumsal karakter, davranış ve değerlerine sahip, sosyobilimsel konulara hakim, iletişim ve işbirliği içinde olan ve ekolojik dünya görüşüne sahip evrensel bireylerin yetiştirilmesi eğitim açısından kaydadeğerdir. Bütün bunlar dikkate alındığında Mun vd. (2015) tarafından geliştirilen ve Çelik (2016) tarafından Türkçe'ye uyarlanan evrensel fen okuryazarlığ ölçeği'nin hem fen bilimleri öğretim programının vizyonuyla örtüşmesi, hem de yenilenen programdaki fen okuryazarlık boyutlarının birçoğu ile uyuşması, bu ölçme aracının fen okuryazarlığı konusundaki geçerliliğini göstermektedir. Evrensel fen okuryazarlığının ulusal alanyazındaki yansımalarına bakılacak olursa; fen ve teknoloji okuryazarlığı, bilim okuryazarlığı veya bilimsel okuryazarlık gibi farklı şekillerde kullanıldığı görülmektedir. Alanyazında yapılan çalışmalar daha ziyade fen okuryazarlığı ile ilgili olup, evrensel fen okuryazarlığı ile ilgili yurt içinde yapılmış az çalışma bulunmaktadır. Bu çalışmalardan bazıları; Çelik (2016), Çelik ve Can (2017) ve Can ve Çelik (2020) tarafından yapılmıştır. Ayrıca, alanyazında ortaokul öğrencilerinin evrensel fen okuryazarlık düzeylerinin belirlenmesi ile ilgili yapılmış bir çalışmaya da rastlanılamamıştır. Bu açıdan bakıldığında araştırmanın alanyazına önemli bir katkı sağlayacağı düşünülmektedir. Programlara genel olarak bakıldığında özellikle son programlarda bireysel farklılıkları ne olursa olsun bütün öğrencilerin fen okuryazarı bireyler olarak yetiştirilmesi amaçlanmıştır (MEB, 2005; 2013). Bu amaç doğrultusunda araştırmanın problemi; "ortaokul öğrencilerinin evrensel fen okuryazarlık düzeyleri nasıl değişmektedir?” olarak tanımlanmıştır. Bu problemi cevaplandırmada kullanılan alt problemler ise:

1. Ortaokul öğrencilerinin evrensel fen okuryazarlığı hangi düzeydedir?

2. Ortaokul öğrencilerinin evrensel fen okuryazarlık düzeyi;

a) Anne eğitim seviyesine,

b) Baba eğitim seviyesine,

c) Sinıf seviyesine, 
d) Cinsiyete,

göre anlamlı bir farklılık göstermekte midir? olarak belirlenmiştir.

\section{YÖNTEM}

\section{Araştırma Modeli}

Ortaokul öğrencilerinin evrensel fen okuryazarlık düzeylerini (EFOYD) ve bazı değişkenlerin bu düzeye etkisini belirlemeyi amaçlayan bu araştırmada, tarama modeli kullanılmıştır. Tarama modelleri, geçmişte ya da halen var olan bir durumu olduğu gibi betimlemeyi amaçlayan araştırma yaklaşımlarıdır. Araştırmaya konu olan birey, nesne ya da olaylar kendi koşulları içerisinde ve olduğu gibi tanımlanmaya çalışılır (Karasar, 2015).

\section{Katılımcilar}

Araştırmanın katılımcıları, Kastamonu İl Merkezindeki devlet ortaokullarında öğrenim gören ve rastgele olarak seçilen 1674 altıncı, yedinci ve sekizinci sınıf öğrencilerinden oluşmaktadır. Araştırmaya katılan öğrencilerin kişisel özellikleri Tablo 2'de verilmiştir.

Tablo 2. Öğrencilerin Kişisel Özelliklerine Göre Frekans (f) ve Yüzde (\%) Dă̆ılımı

\begin{tabular}{|c|c|c|c|}
\hline Değişkenler & Gruplar & $f$ & $\%$ \\
\hline \multirow{2}{*}{ Cinsiyet } & $\mathrm{K} 1 \mathrm{Z}$ & 822 & 49,1 \\
\hline & Erkek & 852 & 50,9 \\
\hline \multirow{3}{*}{ Sinif Seviyesi } & Altıncr & 469 & 28,0 \\
\hline & Yedinci & 867 & 51,8 \\
\hline & Sekizinci & 338 & 20,2 \\
\hline \multirow{6}{*}{ Anne Eğitim Seviyesi } & Yüksek Lisans/Doktora & 67 & 4,0 \\
\hline & Üniversite & 323 & 19,3 \\
\hline & Lise & 427 & 25,5 \\
\hline & Ortaokul & 380 & 22,7 \\
\hline & İlkokul & 425 & 25,4 \\
\hline & Diğer & 52 & 3,1 \\
\hline \multirow{6}{*}{ Baba Eğitim Seviyesi } & Yüksek Lisans/Doktora & 113 & 6,7 \\
\hline & Üniversite & 413 & 24,7 \\
\hline & Lise & 589 & 35,2 \\
\hline & Ortaokul & 339 & 20,2 \\
\hline & İlkokul & 185 & 11,1 \\
\hline & Diğger & 35 & 2,1 \\
\hline
\end{tabular}

\section{Veri Toplama Arac1}

Araştırmada, ortaokul öğrencilerinin evrensel fen okuryazarlık düzeyini belirlemek ve evrensel fen okuryazarlık düzeyinin bazı değişkenlere göre değişip değişmediğini tespit etmek amacıyla Evrensel Fen Okuryazarlığı Ölçeği (EFOYÖ) kullanılmıştır.

\section{Evrensel Fen Okuryazarlığı Ölçeği (EFOYÖ)}

Evrensel Fen Okuryazarlığı Ölçeği (EFOYÖ), 2015 yılında Mun vd. tarafından, 21. yüzyılın sosyal ve toplumsal karakter, davranış ve değerlerine sahip, sosyobilimsel konulara hâkim evrensel bireylerin yetiştirilmesi temeline dayandırılarak hazırlanmıştır. Ölçek 48 maddeden oluşan beşli likert tipindedir ve Cronbach alpha iç tutarlılık katsayısı 0,91 olarak bulunmuştur 
(Mun vd., 2015). Ayrıca fen okuryazarlığına kazandırılan evrensellik kavramı, toplumdaki her bireyin evrensel bir vatandaş olarak görülmesine dayanmaktadır. Bu ölçek, Çelik (2016) tarafından Türkçe' ye uyarlanmış ve ölçeğin geçerlik ve güvenirlik çalışmaları yapılmış ve 645 fen bilgisi öğretmen adayına uygulanarak test edilmiştir. Pilot çalışma sonucunda elde edilen veriler, doğrulayıcı faktör analizi ile denenmiştir. Analiz sonucunda elde edilen uyum indeksleri ölçeğin Türkçe' ye uyarlanmasında geçerliğin sağlandığını göstermiştir. Ölçeğin güvenirliği ise, Cronbach alpha iç tutarlılık katsayısı ile hesaplanmış ve bu değer 0,91 olarak bulunmuştur (Çelik, 2016). EFOYÖ; "Kesinlikle Katılmıyorum (1)", "Katılmıyorum (2)", "Kararsızım (3)", "Katılıyorum (4)" ve "Kesinlikle Katılıyorum (5)" şeklinde beşli likert tipinde bir ölçektir. Ölçekten alınabilecek maksimum puan 240, minimum puan ise 48 'dir. Türkçe'ye uyarlanan bu ölçek için gerekli izinler alınarak bu araştırmada kullanılmasına karar verilmiştir.

Alanyazında bu ölçeğin kullanılmasıyla ilgili araştırmalar incelendiğinde; Çelik (2016) araştırmasında, "Evrensel Fen Okuryazarlığı Ölçeği" nin Türkçe’ye uyarlanmasını yapmış ve uyarlanan bu ölçeği Türkiye'nin 12 farklı istatistiki bölgesindeki 20 farklı üniversitede öğrenim gören dördüncü sınıf fen bilgisi öğretmen adaylarının evrensel fen okuryazarlık düzeyini belirlemek amacıyla kullandığı tespit edilmiştir. Çelik ve Can (2017) araştırmalarında, evrensel fen okuryazarlık ölçeğinin kültürler arası uyum ve geçerlilik çalışmasını yapmışlardır. Araştırmalarının katılımcılarını Türkiye'de altı farklı üniversitede öğrenim gören 645 fen bilgisi öğretmen adayı oluşturmaktadır. Araştırmalarında, evrensel fen okuryazarlık ölçeğinin alanyazına katkı sağlayabilecek nitelikte geçerli bir ölçek olduğu sonucuna ulaşmışlardır. Can ve Çelik (2020) araştırmalarında ise, fen bilgisi öğretmen adaylarının Türkiye İstatistiki Bölge Birimlerine göre evrensel fen okuryazarlık düzeylerini tespit etmeyi amaçlamışlardır.

\section{Verilerin Toplanması}

Araştırmanın katılımcıları için Kastamonu İl Milli Eğitim Müdürlüğü'nden ve Kastamonu Üniversitesi Sosyal ve Beşeri Bilimler Araştırma ve Yayın Etik Kurul Başkanlığı'ndan (Tarih: 25.12.2020; Sayı: 4/22) gerekli izinler alınmış ve gönüllülük esasına göre araştırmaya başlanılmıştır. Uygulanan ölçek; katılımcıların demografik özelliklerini içeren birinci kısım ve 48 maddeden oluşan ikinci kısım olmak üzere iki bölümden oluşmaktadır. EFOYÖ uygulanmadan önce ilk kısmı katılımcılara göre düzenlenmiş ve sonra uygulama yapılmıştır. Ölçeğin ortaokul öğrencilerine uygulanmasında özellikle ölçekteki bazı maddelerin öğrenciler tarafından daha iyi anlaşılması için araştırmacı tarafından gerekli açıklamalar yapılmış ve öğrencilerin kafalarında herhangi bir soru işaretinin kalmaması sağlanmıştır. Ölçekte yer alan kavramlar ortaokul öğrencilerinin de anlayabileceği düzeyde olduğu için ölçeği uygulama esnasında herhangi bir sorunla karşılaşılmamıştır. Ancak, araştırmacı yine de öğrencilerin zorlanabileceği bazı kelimeleri (global=küresel vb.) uygulamadan önce öğrencilerle paylaşmış ve tahtaya kısa açıklamalar şeklinde not almıştır. İhtiyaç halinde öğrencilerin bireysel soruları da yanlı olmayacak şekilde cevaplandırılmıştır. Ayrıca ölçeğin, katılımcı grubuna dahil olmayan ortaokul öğrencilerine ön uygulaması yapılarak, ölçekteki her bir maddenin anlaşılırlığı test edilmiş ve verilecek süre belirlenmiştir. Ölçek, katılımcı grubu için istenilen sayıda çoğaltılarak araştırmacılar tarafından 30 dakika süreyle uygulanmıştır. Ölçek dağıtılmadan önce öğrencilere bunun bir akademik çalışma olduğundan, not etkisinin olmadığından ve elde edilen verilerin sadece bu araştırma için kullanılacağından bahsedilmiş ve böylece ölçeği cevaplamada samimi olmaları ve gerçekleri yansıtmaları istenmiştir. Ölçme 
aracına samimi cevaplar vermediği düşünülen veya ölçeğin önemli bir kısmının boş bırakıldığı görülen öğrencilerin ölçeklerinden 26 tanesi değerlendirmeye alınmamıştır.

Ortaokul öğrencilerinden altıncı, yedinci ve sekizinci sınıfların alınmasının sebebi; bu seviyelerdeki öğrencilerin fen kavramları ile ilgili bilgilere sahip olma, bir problemle karşılaştıklarında çözüm yolları üretebilme, fenden yararlanabilme ve deney yapabilme gibi becerilere daha hakim oldukları düşünülmüştür. Ortaokul öğrencilerinin seçilmesinin diğer bir sebebi ise; üç yılda bir uygulanan ve 15 yaş grubu öğrencilerin girdiği PISA uygulaması için kendi evrensel fen okuryazarlıkları hakkında bir ön bilgi sahibi olmalarının amaçlanmasıdır. Öğrencilerin fen okuryazarlıklarının da ölçüldüğü bu sınavlarda farkındalık oluşturmak onların fen başarılarını artırmalarında ve fene karşı olumlu tutum geliştirmelerinde önemli olabilir. Ayrıca ölçek, öğrencilere bahar döneminin sonlarına doğru uygulanmıştır. Burada amaç, fenle ilgili daha çok kavrama sahip olmalarıdır.

\section{Verilerin Analizi}

Araştırmanın amacı doğrultusunda toplanan verilerin analizleri bir istatistik paket programı kullanılarak yapılmıştır. Hangi testlerin kullanılacağına dair karar vermeden önce, elde edilen verilerin normal dağılım gösterip göstermediğine bakılmıştır. Bu çalışmada, EFOYÖ'den elde edilen verilerin normallik testine yönelik örneklem büyüklüğü $35^{\prime}$ ten büyük olduğu için Kolmogorov Smirnov testi (McKillup, 2012) kullanılmış ve elde edilen veriler Tablo 3'te gösterilmiştir.

Tablo 3. EFOYÖ'den Elde Edilen Verilerin Normallik Testi Sonuçları

\begin{tabular}{lllll}
\hline & $\mathbf{N}$ & $\overline{\mathbf{X}}$ & SS & $p$ \\
\hline EFOYÖ & 1674 & 179,21 & 33,995 & $0,000^{*}$ \\
\hline${ }^{*} p<0,05$ & & & &
\end{tabular}

Tablo 3'te görüldüğ̈̈ gibi, öğrencilerin normallik testi sonucu ise $p<0,05$ olduğu için, EFOYÖ' den elde edilen verilerin normal dağılım göstermediği belirlenmiş ve bundan sonraki aşamalarda öğrencilerden elde edilen verilerin analizlerinde parametrik olmayan testler kullanılmıştır. Öğrencilerin EFOYD'si betimsel istatistik ile belirlenmiştir. EFOYD’nin anne ve baba eğitimine ve sinıf seviyesine göre değişimi Kruskal-Wallis testi kullanılarak tespit edilmiş, cinsiyet değişkeninin etkisi ise Mann-Whitney U testi ile çözümlenmiştir.

\section{BULGULAR}

$\mathrm{Bu}$ bölümde, araştırmanın amacı doğrultusunda öğrencilerin fen okuryazarlık düzeyine ait bulgular, araştırmanın alt problemleri ile ilişkilendirilerek aşağıdaki gibi yorumlanmıştır.

\section{Birinci Alt Probleme İlişkin Bulgular}

Araştırmanın birinci alt problemi, ortaokul öğrencilerinin evrensel fen okuryazarlıklarının hangi düzeyde olduğunu tespit etmektir. Bu amaçla, Kastamonu İl Merkezindeki devlet ortaokullarının altıncı, yedinci ve sekizinci sınıflarında öğrenim gören 1674 öğrencinin EFOYÖ'ye verdikleri cevaplar, ölçeğin beşli likert tipine göre gruplandırılmış ve bu cevaplardan elde edilen puanların frekans ve yüzdelik dağılımları Tablo 4'te gösterilmiştir. 
Tablo 4. Ortaokul Öğrencilerinin EFOYD Sonuçları

\begin{tabular}{cccccccccc}
\hline \multicolumn{2}{c}{ Çok Yüksek } & \multicolumn{2}{c}{ Yüksek } & \multicolumn{2}{c}{ Orta } & \multicolumn{2}{c}{ Düsïu } & \multicolumn{2}{c}{ Çok Düşük } \\
\hline \multicolumn{2}{c}{$240-201,7$} & $201,6-163,4$ & \multicolumn{2}{c}{$163,3-124,9$} & \multicolumn{2}{c}{$124,8-86,5$} & \multicolumn{2}{c}{$86,4-48,0$} \\
\hline f & $\%$ & f & \% & f & \% & f & \% & f & \% \\
\hline 424 & 25,33 & 779 & 46,53 & 356 & 21,27 & 84 & 5,02 & 31 & 1,85 \\
\hline
\end{tabular}

Tablo 4'te görüldüğ ̈̈u gibi, öğrencilerin yaklaşık \%25'inin "çok yüksek", \%46,5'inin "yüksek", \%21'inin "orta", \%5'inin "düşük" ve yaklaşık \%2'sinin ise "çok düşük" seviyelerde oldukları bulunmuştur. Tablodan da anlaşılacağı üzere öğrencilerin çoğunluğunun fen okuryazarlık düzeyi bakımından “yüksek" seviyede olduğu tespit edilmiştir.

Ortaokul öğrencilerinin EFOYÖ'den aldıkları en düşük ve en yüksek puanlar ile alınan puanların ortalaması ve standart sapma değerleri Tablo 5 'te gösterilmiştir.

Tablo 5. Ortaokul Öğrencilerinin EFOYÖ Sonuçlan

\begin{tabular}{lccccc}
\hline & $\mathbf{N}$ & $\begin{array}{c}\text { Minimum } \\
\text { Puan }\end{array}$ & $\begin{array}{c}\text { Maksimum } \\
\text { Puan }\end{array}$ & $\overline{\mathbf{X}}$ & SS \\
\hline EFOYÖ & 1674 & 48 & 240 & 179,2 & 34,0 \\
\hline
\end{tabular}

Tablo 5'e göre, araştırmaya katılan ortaokul öğrencilerinin aldığ en düşük puan 48, en yüksek puan 240'tır. Öğrencilerin EFOYÖ'den aldıkları puanların ortalaması 179,2 olup bu değer genel olarak ortaokul altıncı, yedinci ve sekizinci sınıf öğrencilerinin EFOYD'nin "yüksek" olduğunu göstermektedir.

\section{İkinci Alt Probleme İlişkin Bulgular}

Araştırmanın ikinci alt problemi, ortaokul öğrencilerinin EFOYD'nin anne eğitim seviyesine, baba eğitim seviyesine, sinıf seviyesine ve cinsiyete göre anlamlı bir farklılık gösterip göstermediğini tespit etmektir. Bu amaçla, öğrencilerin EFOYÖ’ye verdikleri cevaplar ve elde edilen bulgular tablolar halinde aşağıda verilmiştir. Ortaokul altıncı, yedinci ve sekizinci sınıf öğrencilerinin EFOYD'nin anne eğitim seviyesine göre değişimi Kruskal-Wallis testi kullanılarak tespit edilmiş ve elde edilen veriler Tablo 6 ' da verilmiştir.

Tablo 6. Ortaokul Öğrencilerinin EFOYÖ Puanlarının Anne Eğitim Seviyesi Değişkenine Ilişkin Kruskal-Wallis Testi Sonuçları

\begin{tabular}{|c|c|c|c|c|c|c|}
\hline & & $\mathbf{N}$ & $\begin{array}{l}\text { Sira } \\
\text { Ortalamaları }\end{array}$ & SD & $\begin{array}{l}\text { Ki-Kare } \\
(\chi 2)\end{array}$ & $p$ \\
\hline \multirow{6}{*}{$\begin{array}{l}\text { Anne Eğitim } \\
\text { Seviyesi }\end{array}$} & YL/Doktora & 67 & 824,16 & \multirow{6}{*}{5} & \multirow{6}{*}{25,041} & \multirow{6}{*}{0,000} \\
\hline & Üniversite & 323 & 931,63 & & & \\
\hline & Lise & 427 & 827,80 & & & \\
\hline & Ortaokul & 380 & 823,35 & & & \\
\hline & İlkokul & 425 & 818,37 & & & \\
\hline & Diğer & 52 & 609,41 & & & \\
\hline
\end{tabular}

$p<0,05$ 
Tablo 6'da gösterildiği gibi, Kruskal-Wallis testi analizi sonuçlarına göre ortaokul öğrencilerinin EFOYD'de anne eğitim seviyesine göre aralarında istatistiksel olarak anlamlı bir fark olduğu $(p<0,05)$ tespit edilmiştir. Diğer bir ifadeyle, öğrencilerin anne eğitim seviyesi, onların EFOYD'yi etkileyen faktörlerden biri olduğu tespit edilmiştir. Tablo 6'da görüldüğü gibi, anne eğitim seviyesi üniversite olan öğrencilerin EFOYD'yi en yüksek $(931,63)$, diğer olan öğrencilerin EFOYD'si en düşük $(609,41)$ olarak tespit edilmiştir.

Ortaokul altıncı, yedinci ve sekizinci sınıf öğrencilerinin EFOYD'nin baba eğitim seviyesine göre değişimi Kruskal-Wallis testi kullanılarak tespit edilmiş ve elde edilen veriler Tablo 7'de verilmiştir.

Tablo 7. Ortaokul Öğrencilerinin EFOYÖ Puanlarının Baba Eğitim Seviyesi Değişkenine İlişkin Kruskal-Wallis Testi Sonuçları

\begin{tabular}{|c|c|c|c|c|c|c|}
\hline & & $\mathbf{N}$ & $\begin{array}{l}\text { Sira } \\
\text { Ortalamaları }\end{array}$ & SD & $\begin{array}{l}\text { Ki-Kare } \\
(\chi 2)\end{array}$ & $p$ \\
\hline \multirow{6}{*}{$\begin{array}{l}\text { Baba Eğitim } \\
\text { Seviyesi }\end{array}$} & YL/Doktora & 113 & 842,70 & \multirow{6}{*}{5} & \multirow{6}{*}{19,094} & \multirow{6}{*}{0,002} \\
\hline & Üniversite & 413 & 920,71 & & & \\
\hline & Lise & 589 & 816,67 & & & \\
\hline & Ortaokul & 339 & 808,11 & & & \\
\hline & İlkokul & 185 & 796,13 & & & \\
\hline & Diğer & 35 & 692,73 & & & \\
\hline
\end{tabular}

$p<0,05$

Tablo 7'de gösterildiği gibi, Kruskal-Wallis testi analizi sonuçlarına göre ortaokul öğrencilerinin EFOYD'de baba eğitim seviyesine göre aralarında istatistiksel olarak anlamlı bir fark olduğu $(p<0,05)$ tespit edilmiştir. Diğer bir ifadeyle, öğrencilerin baba eğitim seviyesi onların EFOYD'ni etkileyen faktörlerden biri olduğu görülmüştür. Tablo 7'de görüldüğü gibi, baba eğitim seviyesi üniversite olan öğrencilerin EFOYD'yi en yüksek (920,71), diğer olan öğrencilerin EFOYD'si en düşük $(692,73)$ olarak tespit edilmiştir.

Ortaokul altıncl, yedinci ve sekizinci sınıf öğrencilerinin EFOYD’nin sınıf seviyesine göre değişimi Kruskal-Wallis testi kullanılarak tespit edilmiş ve elde edilen veriler Tablo 8'de verilmiştir.

Tablo 8. Ortaokul Öğrencilerinin EFOYÖ Puanlarının Sınıf Seviyesi Değişkenine İlişkin KruskalWallis Testi Sonuçları

\begin{tabular}{lllllll}
\hline & $\mathbf{N}$ & $\begin{array}{l}\text { Sira } \\
\text { Ortalamaları }\end{array}$ & SD & $\begin{array}{l}\text { Ki-Kare } \\
(\chi 2)\end{array}$ & $p$ \\
\hline \multirow{3}{*}{$\begin{array}{l}\text { Sinif } \\
\text { Seviyesi }\end{array}$} & 6 & 469 & 879,19 & & & \\
\cline { 2 - 4 } & 7 & 867 & 793,04 & 2 & 15,394 & 0,000 \\
\cline { 2 - 4 } & 8 & 338 & 893,70 & & & \\
\hline
\end{tabular}

$p<0,05$ 
Tablo 8'de gösterildiği gibi, Kruskal-Wallis testi analizi sonuçlarına göre ortaokul öğrencilerinin EFOYD'de sınıf seviyesine göre aralarında istatistiksel olarak anlamlı bir fark olduğu $(p<0,05)$ tespit edilmiştir. Diğer bir ifadeyle, öğrencilerin sınıf seviyeleri onların EFOYD'yi etkileyen faktörlerden biri olduğu görülmüştür. Tablo 8'de görüldüğü gibi, sekizinci sınıftaki öğrencilerin EFOYD'si en yüksek $(893,70)$, yedinci sınıftaki öğrencilerin EFOYD'si ise en düşük $(793,04)$ olarak tespit edilmiştir.

Ortaokul altıncı, yedinci ve sekizinci sınıf öğrencilerinin EFOYD'nin cinsiyete göre değişimi Mann-Whitney U testi kullanılarak tespit edilmiş ve elde edilen veriler Tablo 9'da verilmiştir.

Tablo 9. Ortaokul Öğrencilerinin EFOYÖ Puanlarının Cinsiyet Değişkenine İlişkin Mann-Whitney U Testi Sonuçları

\begin{tabular}{|c|c|c|c|c|c|c|}
\hline & & $\mathbf{N}$ & $\begin{array}{l}\text { Sira } \\
\text { Ortalamaları }\end{array}$ & $\begin{array}{l}\text { Mann- } \\
\text { Whitney U }\end{array}$ & Z & $p$ \\
\hline \multirow{2}{*}{ Cinsiyet } & $\mathrm{K}_{1 \mathrm{z}}$ & 822 & 889,44 & \multirow{2}{*}{299258,00} & \multirow{2}{*}{$-5,15$} & \multirow{2}{*}{0,000} \\
\hline & Erkek & 852 & 777,74 & & & \\
\hline
\end{tabular}

$p<0,05$

Tablo 9'a göre, ortaokul öğrencilerinin EFOYD'nin cinsiyete göre değişiminde kızların lehine anlamlı bir fark olduğu $(Z=-5,15 ; p<0,05)$ tespit edilmiştir. Diğer bir ifadeyle, öğrencilerin cinsiyet değişkeni onların EFOYD’ni etkileyen faktörlerden biri olduğu görülmüştür.

EFOYÖ'nin demografik bilgilerinin analizi sonucunda, öğrencilerin EFOYD’leri anlamlılık derecelerine göre sıralandığında; sınıf seviyesi $=1$, cinsiyet $=2$, baba eğitim seviyesi=3 ve anne eğitim seviyesi $=4$ olarak tespit edilmiştir. Başka bir ifadeyle ortaokul öğrencilerinin EFOYD'lerinde en etkili sınıf seviyesi, en az etkili ise anne eğitim seviyesinin olduğu görülmüştür.

\section{SONUÇ, TARTIŞMA ve ÖNERILLER}

$\mathrm{Bu}$ araştırmada, ortaokul öğrencilerinin öncelikle evrensel fen okuryazarlık düzeyleri belirlenmiştir. Daha sonra öğrencilerin EFOYD'ye anne ve baba eğitim seviyelerinin, sinıf seviyelerinin ve cinsiyetlerinin etkisinin olup olamadığı araştırılmıştır. Öğrencilerin EFOYÖ'den aldıkları puanların ortalaması, $\overline{\mathrm{X}}=179,2$ 'dir. Bu değer, onların EFOYD'nin yüksek olduğunu göstermektedir. Araştırma sonucunda, 424 öğrencinin EFOYD'nin çok yüksek, 31'inin ise çok düşük olduğu tespit edilmiştir. Bu sonuç, öğrencilerin evrensel fen okuryazarlıklarının istenilen seviyede olduğunu göstermektedir. Nitekim 2018 PISA sonuçlarında, uygulamaya katılan öğrencilerin fen okuryazarlık puan ortalaması, tüm ülkeler içerisinde ilk defa ortalamanın üstüne çıktığı belirtilmiştir (MEB, 2019). TIMSS 2019 raporuna göre ise, dördüncü ve sekizinci sinıflar seviyesinde Türkiye'nin fen performansı daha önceki TIMSS döngülerine kıyasla anlamlı ölçüde artmıştır (MEB, 2020). Bu sonuçlar, ortaokul öğrencilerinin fen okuryazarlıkları açısından istenilen bir durum olarak görülmektedir. Başka bir çalışmada, Čipkova, Karolčik ve Scholzová (2020) ortaokul öğrencileriyle yapmış oldukları araştırmalarının sonucunda, öğrencilerin bilimsel okuryazarlıklarının ortalama düzeyde olduğunu tespit etmişlerdir.

Ortaokul öğrencilerinin EFOYD'ye anne ve babanın eğitim seviyelerinin istatistiksel olarak anlamlı bir etkisinin olduğu tespit edilmiştir. Anne ve baba eğitim seviyeleri üniversite olan 
ortaokul öğrencilerinin EFOYÖ puan ortalamaları, diğer eğitim seviyelerine göre daha yüksek çıkmıştır. Buradan da anne ve babanın fen bilimleri dersine karşı ilgili olduğu, çocuklarını fen bilimleri ile ilgili alanlarda desteklediği, farkındalık oluşturduğu ve feni hem kendilerinin hem de çocuklarının günlük yaşantılarıyla ilişkilendirdikleri sonuçları çıkarılabilir. Alanyazında yapılan ve bu araştırma sonuçlarını destekleyen benzer çalışmalarda mevcuttur. Soysal (2011) çalışmasında, bilimsel okuryazarlık puanlarına anne ve baba eğitim seviyelerinin etki ettiğini tespit etmiştir. Keskin, Tezel ve Acat (2016) yedinci ve sekizinci sınıf öğrencileriyle yapmış olduğu çalışmasında, bilimsel okuryazarlık seviyelerinin anne ve baba eğitim durumuna göre anlamlı düzeyde farklılaştığını belirlemiştir. Süren (2008) çalışmasında, ilköğretim birinci kademe öğrencilerinin bilimsel okuryazarlık düzeylerini ve bilimsel okuryazarlık seviyelerini etkileyen değişkenleri araştırmıştır. 300 öğrencinin katılımı ile gerçekleştirilen araştırmasının sonucunda, birinci kademe öğrencilerinin bilimsel okuryazarlık seviyelerinde anne ve baba eğitim düzeyinin etkili olduğunu tespit etmiştir. Şahin, Sanalan, Bektaş ve Kaygısız (2010) yapmış oldukları araştırmalarında, ilköğretim yedinci sınıf öğrencilerinin fen dersindeki başarısı ile ebeveynlerinin sahip olduğu fen okuryazarlık düzeyi arasındaki ilişkiyi tespit etmeyi amaçlamışlardır. Elde edilen bulgular, hem anne hem de babanın sahip olduğu fen okuryazarlık düzeyinin, öğrencinin seviye belirleme sınavı fen ve teknoloji dersi başarısı üzerinde orta düzey ve pozitif yönde bir ilişkisi olduğunu göstermiştir. Ayrıca, çocukların başarıyı yakalamalarında, fen konularına aşina olan bilimsel düşünme kapasitesine sahip ebeveynlerin çocuklarına yaptıkları doğru ve etkili rehberliğin de etkililiğinden bahsedilmiştir. Çocuklar anne ve babalarıyla uzun süre zaman geçirdikleri için kısa bir süre sonra onları taklit etmeye ve onlar gibi davranmaya başlarlar (Kılıç ve Ünal, 2020). Çocuklar ilk yaşlardan beri fen olaylarına karşı hep meraklı olmuşlardır. Bu durumda çocuğun ailesinin fen ile ilgilenmesi, çocuğun fen etkinlikleri yapmaya ve ileriki yaşamında fene karşı tutumlarının belirlenmesinde etkili olacaktır (Aktamış, Ünal ve Ergin, 2008). Ayrıca, öğrencilerin fen bilimleri dersindeki başarıları, onların anne ve babalarının bu derse verdikleri önemle ilişkili olduğu görülmüştür (Harlan ve Rivkin, 2000).

Ortaokul öğrencilerinin EFOYD'nin okudukları sınıf seviyelerine göre farklılaşıp farklılaşmadığı araştırılmış ve araştırma sonucunda onların EFOYD'ye sınıf seviyesinin etkili bir faktör olduğu tespit edilmiştir. Evrensel fen okuryazarlık puanları sınıf seviyelerine göre; altıncı sinıflarda sira ortalaması 879,19, yedinci siniflarda 793,04 ve sekizinci sinıf sira ortalaması ise 893,70 olarak bulunmuştur. Bu sonuçlar, EFOYD'si en yüksek sekizinci sınıf öğrencilerinde en düşük ise yedinci sinıflarda okuyan öğrencilerde olduğunu göstermektedir. Başka bir ifadeyle, sekizinci sınıf öğrencilerinin altıncı ve yedinci sınıf öğrencilerine göre daha iyi evrensel fen okuryazarı oldukları söylenebilir. Bu durumun sebepleri arasında, sekizinci sınıf öğrencilerinin fen kavramlarına altıncı ve yedinci sınıftakilere nazaran daha fazla sahip oldukları ve LGS sınavına hazırlanmaları gösterilebilir. Sınav sürecinde öğrenciler fen kavramlarını daha hızlı öğrenebilmekte ve öğrendikleri bilgiler kalıcı olabilmektedir. Yedinci sınıfların EFOYD'nin diğer sinıf seviyelerine göre daha düşük olması ise, bu sinıf seviyesindeki fen bilimleri dersi ünite konularının özellikle altıncı sınıf konularından biraz daha ağır olması olarak gösterilebilir. Öğrencilerin, altıncı sınıf fen bilimleri dersi ünite konularını öğrenmede kendilerini daha rahat hissetmeleri ve dolayısıyla da fen bilimleri dersiyle daha çok ilgilenmeleri onların EFOYD'sinin daha yüksek olmasına sebep olabilir. Alanyazında yapılan benzer çalışmalara bakıldığında, bu sonucu destekleyen araştırmaların 
yanında, zıt yönde sonucu olan çalışma da mevcuttur. Soysal (2011) araştırmasında, yedinci ve sekizinci sınıf öğrencilerinin bilimsel okuryazarlık düzeylerini belirlemeyi amaçlamıştır. 846 yedinci sınıf ve 897 sekizinci sınıf öğrencisiyle yaptığı araştırmasının sonucunda, yedinci ve sekizinci sınıfların bilimsel okuryazarlık düzeyleri arasında sekizinci sınıflar lehine anlamlı bir fark olduğunu tespit etmiştir. Duruk (2012) araştırmasında, altıncl, yedinci ve sekizinci sinıflarda öğrenim gören toplam 648 öğrencinin fen ve teknoloji okuryazarlığı seviyesini belirlemeyi amaçlamıştır. Araştırmasının sonucunda, öğrencilerin fen ve teknoloji okuryazarlığı seviyesinin, altıncı ve yedinci sınıflar arasında farklılık göstermediğini, ancak sekizinci sınıf öğrencilerinin bu sınıflardaki öğrencilere göre daha iyi fen ve teknoloji okuryazarı olduklarını tespit etmiştir. Ozan ve Benzer (2018) ortaokul altıncı ve yedinci sınıf öğrencileriye yaptıkları araştırmalarında bilim uygulamaları dersini alan öğrencilerin fen okuryazarlık puan ortalamalarının ( $\left.\bar{X}_{\text {altınc smı }}=15,35 ; \bar{X}_{\text {yedinci smıf }}=15,76\right)$ oldukça birbirine yakın çıktığını tespit etmişlerdir.

Özdem, Çavaş, Çavaş, Çakıroğlu ve Ertepınar (2010) altıncı, yedinci ve sekizinci sınıf öğrencilerinin fen ve teknoloji okuryazarlık seviyesini araştırdıkları çalışmalarının sonucunda ise, sekizinci sınıf öğrencilerinin testin tamamından aldıkları ortalama puanın, altıncı ve yedinci sınıf öğrencilerinin aldıkları ortalama puandan anlamlı şekilde farklılık gösterdiği ve bu farkın sekizinci sınıflar lehine olduğunu belirtmişlerdir. Bunun yanında, Keskin, Tezel ve Acat (2016) yaptığı araştırmasında, ilköğretim ikinci kademe öğrencilerinin fen ve teknoloji dersine ilişkin bilimsel okuryazarlık düzeyini tespit etmeyi amaçlamıştır. Araştırmasını, Kocaeli merkez bölgede rastgele seçilmiş 21 ilköğretim okulunda öğrenim gören 741'i yedinci sınıf, 743'ü ise sekizinci sınıf olmak üzere toplam 1484 öğrenci üzerinde uygulanmıştır. Öğrencilerin sınıf düzeyine göre yedinci sınıf öğrencilerin bilimsel okuryazarlık düzeyinin daha yüksek olduğunu tespit edilmiştir. Bunun da sebebinin yedinci sinıflarda uygulanan yeni programdan dolayı olabileceğini belirtmiştir.

Araştırmada son olarak, ortaokul öğrencilerinin EFOYD'ye cinsiyetin etkili bir faktör olduğu tespit edilmiştir. Başka bir deyişle, kız öğrencilerin EFOYD'ye cinsiyet değişkeninin erkeklere göre istatistiksel olarak anlamlı bir etkisinin olduğu tespit edilmiştir. Bu sonuç, kız öğrencilerin fen kavramlarına yönelik daha meraklı ve daha ilgili olduklarından kaynaklanabilir. PISA 2018' e göre ise, fen alanında erkek öğrencilerin ortalama puanının 464,6, kız öğrencilerin ortalama puanının ise 472 olduğu belirlenmiştir (MEB, 2019). Alanyazında yapılan çalışmalarda da benzer sonuçlar bulunmuştur. Soysal (2011) öğrencilerin cinsiyete göre bilimsel okuryazarlıklarını incelediği araştırmasında, kız öğrenciler lehine anlamlı bir fark çıktığını tespit etmiştir. Kız öğrencilerin erkek öğrencilere nazaran daha başarılı olduğu bu durumu, kız öğrencilerin merak düzeylerinin ve ilgilerinin erkek öğrencilerden daha yüksek olmasına bağlamıştır. Keskin, Tezel ve Acat (2016) çalışmalarında, ortaokul öğrencilerinin fen ve teknoloji dersine ilişkin bilimsel okuryazarlık seviyelerini araştırmışlardır. Araştırmalarının sonucunda, bilimsel okuryazarlık toplam puan ortalamasının kızlar lehine farklılaştığını tespit etmişlerdir. Sonuç olarak, yurtiçinde yapılan araştırmalar incelendiğinde, yukarıda bahsedildiği gibi bazı çalışmalarda katılımcıların fen okuryazarlık düzeyine cinsiyet değişkeninin etkili olduğu, bazı çalışmalarda ise (Duruk, 2012; Woods-McConney, Oliver, McConney, Schibeci ve Maor, 2014). bu değişkenin etkili olmadığ1 yönünde sonuçlara ulaşılmıştır. Cinsiyet değişkeninin etkili olduğu çalışmalarda ise genellikle, kızların erkeklere göre fen okuryazarlık düzeylerinin daha yüksek olduğu tespit edilmiştir. 


\section{Öneriler}

Araştırmada ulaşılan sonuçlara göre geliştirilen öneriler aşağıda maddeler halinde verilmiştir:

1. Bu araştırmada, altıncı, yedinci ve sekizinci sınıf öğrencilerinin evrensel fen okuryazarlık düzeyleri tespit edilmiş ve bu düzeyin bazı değişkenlere göre nasıl farklılaştığı araştırılmıştır. Nicel olarak elde edilen bu sonuçlar, nitel bir çalışma ile desteklenerek daha detaylı bilgiler ortaya konulabilir.

2. Araştırmada, kız ve erkek öğrencilerin evrensel fen okuryazarlık düzeyleri arasında anlamlı bir fark bulunmuştur. Bu farkın nereden kaynaklandığına ve nasıl azaltılabilir yönünde araştırmalar yapılabilir.

3. Araştırmaya katılan öğrencilerin anne ve babalarının eğitim seviyelerinin onların evrensel fen okuryazarlık düzeylerini etkilediği görülmüştür. Bundan dolayı, ebeveynler fen bilimleri dersinin önemi hakkında daha da bilgilendirilebilirler.

\section{KAYNAKÇA}

AAAS (1993). Benchmarks for science literacy, project 2061. New York: Oxford University Press.

Aktamış, A., Ünal, A., \& Ergin, P. (2008). Öğrencilerin fene yönelik tutumlarına ailelerinin etkisi. Sosyal Politika Çalışmaları Dergisi, 14(14), 39-48.

Anıl, D., Özkan, Y. Ö., \& Demir, E. (2015). PISA 2012 Araştırması ulusal nihai raporu. Ankara: Milli Eğitim Bakanlığı, PISA Uluslararası Öğrenci Değerlendirme Programı.

Boyes, E., Skamp, K., \& Stanistreet, M. (2009). Australian secondary students' views about global warming: Beliefs about actions, and willingness to act. Research in Science Education, 39, 661-680.

Bybee, R. W. (1997). Achieving scientific literacy: From purposes to practices. Portsmouth, NH: Heinemann.

Can, Ş., \& Çelik, C. (2020). Fen bilgisi öğretmen adaylarının Türkiye istatistiki bölge birimlerine göre evrensel fen okuryazarlık düzeyi. Pamukkale Üniversitesi Eğitim Fakültesi Dergisi, 49, 112-133.

Cappellaro, E. (2018). Multidisciplinary studies-4 (educational sciences), Ed. Şahin, H., (1th Edition). Levels of basic and integrated science process skills of preservice primary school teachers, p. 93114. Podgorica, Montenegro.

Čipková, E., Karolčík, S., \& Scholzová, L. (2020) Are secondary school graduates prepared for the studies of natural sciences?-evaluation and analysis of the result of scientific literacy levels achieved by secondary school graduates. Research in Science $\mathcal{E}$ Technological Education, 38(2), 146-167. 
Çelik, C. (2016). Evrensel fen okuryazarlık ölçeği'nin Türkçe'ye uyarlama çalışması ve öğretmen adaylarının evrensel fen okuryazarlık düzeyi. Yayınlanmamış yüksek lisans tezi, Muğla Sitkı Koçman Üniversitesi Eğitim Bilimleri Enstitüsü.

Çelik, C., \& Can, Ş. (2017). Intercultural adaptation and validity study: universal science literacy scale (USLS). Universal Journal of Educational Research, 5(12), 2125-2136.

Duruk, Ü. (2012). İlköğretim ikinci kademe öğrencilerinin fen ve teknoloji okuryazarlı̆̆ı seviyesinin belirlenmesi. Yayınlanmamış yüksek lisans tezi, Kocaeli Üniversitesi Fen Bilimleri Enstitüsü, Kocaeli.

Gömleksiz, M., Yaşar, Ş., Sağlam, M., Hakan, A., Sözer, E., Gözütok, D., Saylan, N., Battal, N., Yıldırım, G., Kaya, Z., Ulusoy, A., Aksu, M., \& Yıldırım, A. (2006). Yeni öğretim programlarını inceleme ve değerlendirme raporu. İlköğretim Online, 5(1), 1-215.

Harlan, J. D., \& Rivkin, M. S. (2000). Science experiences for the early childhood years: An integrated approach. USA: Prentice-Hall, Inc.

Hurd, P. D. (1958). Science literacy: Its meaning for American schools. Educational Leadership, 16(7), 13-16.

Karasar, N. (2015). Bilimsel araştırma yöntemi. (28. Basım). Ankara: Nobel Akademik Yayıncılık.

Kaya, M., \& Bacanak, A. (2013). Fen ve teknoloji öğretmen adaylarının düşünceleri: fen okuryazarı birey yetiştirmede öğretmenin yeri. Dicle Üniversitesi Ziya Gökalp Eğitim Fakültesi Dergisi, 21, 209-228.

Keskin, H., Tezel, Ö., \& Acat, B. (2016). Ortaokul öğrencilerinin fen ve teknoloji dersine ilişkin bilimsel okuryazarlık seviyeleri. The Journal of Academic Social Science Studies, 47, $1-18$.

Kılıç, R., \& Ünal, M. (2020). Ebeveynlerin okul öncesi dönemde fen ve fen etkinlikleri hakkındaki görüşlerinin incelenmesi (Elazı̆̆ ili örneği). Mehmet Akif Ersoy Üniversitesi Eğitim Bilimleri Enstitüsü Dergisi, 8(10), 1-20.

Kurtuluş, N., \& Çavdar, O. (2011). Fen ve teknoloji öğretim programındaki etkinliklere yönelik öğretmen ve öğrenci düşünceleri. Necatibey Eğitim Fakültesi Elektronik Fen ve Matematik Eğitimi Dergisi, 5(1), 1-23.

McKillup, S. (2012). Statistics explained: An introductory guide for life scientists. (2 ${ }^{\text {th }}$ Edition). United States: Cambridge University Press.

MEB (2005). Ilköğretim fen ve teknoloji (4 ve 5. sinıflar) öğretim programı. Ankara: MEB.

MEB (2006). Ilköğretim fen ve teknoloji dersi (6, 7 ve 8. Sinıflar) öğretim programı. Ankara: MEB.

MEB (2013). Fen bilimleri dersi öğretim programı (İlkokul ve Ortaokul 3, 4, 5, 6, 7 ve 8. Sinıflar). Ankara: MEB.

MEB (2018). Fen bilimleri dersi öğretim programı (İlkokul ve Ortaokul 3, 4, 5, 6, 7 ve 8. Sinıflar). Ankara: MEB.

MEB (2019). PISA 2018 Türkiye ön raporu. Ankara. 21 May1s 2020 tarihinde http://www.meb.gov.tr/meb_iys_dosyalar/2019_12/03105347_PISA_2018_Turkiye_on_ra poru.pdf adresinden alınmıştır. 
MEB (2020). TIMSS 2019 Türkiye ön raporu. Eğitim Analiz ve Değerlendirme Raporları Serisi No: 15. Ankara: MEB.

Mueller, M. P., \& Zeidler, D. L. (2010). Moral-ethical character and science education: Ecojustice ethics through socioscientific issues (SSI). In D. Tippins, M. Mueller, M. van Eijck, \& J. Adams (Eds.). Cultural studies and environmentalism: The confluence of ecojustice, place-based (science) education, and indigenous knowledge systems. (pp. 105-128). New York, NY: Springer.

Mun, K., Shin, N., Lee, H., Kim, S. W., Choi, K., Choi, S. Y., \& Krajcik, J. S. (2015). Korean secondary students' perception of scientific literacy as global citizens: Using global scientific literacy questionnaire. International Journal of Science Education, 37(11), 17391766.

OECD (2019). PISA 2018 assessment and analytical framework, PISA. Paris: OECD Publishing.

Ozan, Ü., \& Benzer, S. (2018). Seçmeli bilim uygulamaları dersinin öğrencilerin fen okuryazarlığı-fene yönelik tutumlarına etkisi ve öğretmenlerin ders hakkındaki görüşlerinin incelenmesi. Dicle Üniversitesi Ziya Gökalp Eğitim Fakültesi Dergisi, (34), 22-37.

Özdem, Y., Çavaş, P., Çavaş, B., Çakıroğlu, J., \& Ertepınar H. (2010). An investigation of elementary students scientific literacy levels. Journal of Baltic Science Education, 9(1), 619.

Roth, W. M., \& Lee, S. (2004). Science education as/for participation in the community. Science Education, 88(2), 263-291.

Soylu, H. (2004). Fen öğretiminde yeni yaklaşımlar. Keşif yoluyla öğrenme. Ankara: Nobel Akademik Yayıncılık.

Soysal, M. (2011). Öğrencilerin fen ve teknoloji dersindeki başarıları ile fen okuryazarlı̆̆ı düzeylerinin karşılaştırlması ve öğretmenlerin fen okuryazarlı̆̆ı ile ilgili görüşlerinin incelenmesine yönelik bir çalışma. Yayınlanmamış yüksek lisans tezi, Çukurova Üniversitesi Sosyal Bilimler Enstitüsü, Ankara.

Süren, T. (2008). İlköğretim birinci kademe öğrencilerinde bilimsel okuryazarlı düzeyi. Yayınlanmamış yüksek lisans tezi, Afyon Kocatepe Üniversitesi Sosyal Bilimler Enstitüsü, Afyon.

Şahin, R., Sanalan, A., Bektaş, Ö., \& Kaygısız, Y. (2010). Ebeveynlerin fen okuryazarlık düzeylerinin ilköğretim 7. sınıf öğrencilerin fen ve teknoloji dersi başarılarına etkisi. Erzincan Üniversitesi Fen Bilimleri Enstitüsü Dergisi, 3(1), 125-143.

Tal, T., \& Kedmi, Y. (2006). Teaching socioscientific issues: classroom culture and students' performances. Science and Education, 1, 615-644.

Woods-McConney, A., Oliver, M. C., McConney, A., Schibeci, R., \& Maor, D. (2014) Science engagement and literacy: A retrospective analysis for students in Canada and Australia. International Journal of Science Education, 36(10), 1588-1608.

Yetişir, M. İ., Batı, K., Kahyaoğlu, M., \& Birel, F. K. (2018). Dezavantajlı öğrencilerin fen okuryazarlık performanslarının duyuşsal özellikleriyle ilişkisinin incelenmesi. Ankara Üniversitesi Ĕ̆itim Bilimleri Fakültesi Dergisi, 51(1), 143-158. 
Yetişir, M. İ., \& Kaptan, F. (2007). Sınıf Öğretmeni adaylarının fen ve teknoloji okuryazarlığının önemi hakkındaki görüşleri. Uluslararası Öğretmen Yetiştirme Politikaları ve Sorunları Sempozyumu, Hacettepe Üniversitesi ve Azerbaycan Devlet Pedagoji Üniversitesi, Uluslararasi Öğretmen Yetiştirme Politikaları ve Sorunları Sempozyumu, 12-14 Mayıs, Bakü, Azerbaycan.

Zeidler, D. L., Herman, B. C., Ruzek, M., Linder, A., \& Lin, S. (2013). Cross-cultural epistemological orientations to socioscientific issues. Journal of Research in Science Teaching, 50(3), 251-283. 